Article

\title{
Avicequinone C Isolated from Avicennia marina Exhibits 5a-Reductase-Type 1 Inhibitory Activity Using an Androgenic Alopecia Relevant Cell-Based Assay System
}

Ruchy Jain ${ }^{1,2}$, Orawan Monthakantirat ${ }^{3}$, Parkpoom Tengamnuay ${ }^{1}$ and Wanchai De-Eknamkul ${ }^{2,4, *}$

1 Department of Pharmaceutical Technology, Faculty of Pharmaceutical Sciences, Chulalongkorn University, Bangkok 10330, Thailand; E-Mails: ruchyj@gmail.com (R.J.); parkpoom.t@chula.ac.th (P.T.)

2 Research Unit of Natural Product Biotechnology, Faculty of Pharmaceutical Sciences, Chulalongkorn University, Bangkok 10330, Thailand

3 Division of Pharmaceutical Chemistry, Faculty of Pharmaceutical Sciences, Khon Kaen University, Khon Kaen 40002, Thailand; E-Mail: oramon@kku.ac.th

4 Department of Pharmacognosy and Pharmaceutical Botany, Faculty of Pharmaceutical Sciences, Chulalongkorn University, Bangkok 10330, Thailand

* Author to whom correspondence should be addressed; E-Mail: dwanchai@chula.ac.th; Tel./Fax: +66-2-218-8393.

Received: 8 April 2014; in revised form: 18 May 2014 / Accepted: 19 May 2014 /

Published: 23 May 2014

Abstract: Avicennia marina (AM) exhibits various biological activities and has been traditionally used in Egypt to cure skin diseases. In this study, the methanolic heartwood extract of AM was evaluated for inhibitory activity against $5 \alpha$-reductase (5 $\alpha$-R) [E.C.1.3.99.5],

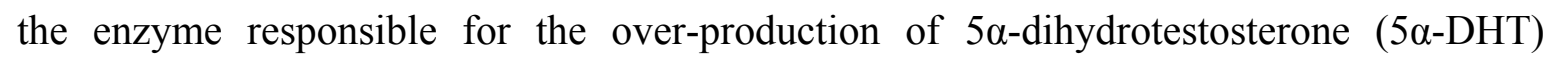
causing androgenic alopecia (AGA). An AGA-relevant cell-based assay was developed using human hair dermal papilla cells (HHDPCs), the main regulator of hair growth and the only cells within the hair follicle that are the direct site of $5 \alpha$-DHT action, combined with a non-radioactive thin layer chromatography (TLC) detection technique. The results revealed that $\mathrm{AM}$ is a potent $5 \alpha-\mathrm{R}$ type $1(5 \alpha-\mathrm{R} 1)$ inhibitor, reducing the $5 \alpha$-DHT production by $52 \%$ at the final concentration of $10 \mu \mathrm{g} / \mathrm{mL}$. Activity-guided fractionation has led to the identification of avicequinone $\mathrm{C}$, a furanonaphthaquinone, as a $5 \alpha-\mathrm{R} 1$ inhibitor with an $\mathrm{IC}_{50}$ of $9.94 \pm 0.33 \mu \mathrm{g} / \mathrm{mL}$ or $38.8 \pm 1.29 \mu \mathrm{M}$. This paper is the first to report anti-androgenic activity through $5 \alpha-\mathrm{R} 1$ inhibition of $\mathrm{AM}$ and avicequinone $\mathrm{C}$. 
Keywords: avicequinone C; Avicennia marina; $5 \alpha-\mathrm{R} 1$ inhibitory activity; cell-based bioassay

\section{Introduction}

Avicenna marina (AM), commonly called the grey or white mangrove, is a species of mangrove trees belonging to the Acanthaceae family. Traditionally it is used in Egypt to cure skin diseases [1] against fish stings, ringworms, sores, boils, skin ulcers and scabies [2]. It has also been used as a contraceptive [2] and in treating rheumatism [3]. In the literature, AM has been reported to exhibit antifertility [4], anticancer [5], antimicrobial [6] and antitumor [7] activities. Phytochemically, AM has been found to contain a variety of natural product groups, including naphthalene derivatives, flavones, iridoid glucosides, prenylpropanoid glycosides, abietane ditrerpenoid glucosides, flavonoid terpenoids and steroids [1].

AM has been used as a contraceptive due to its effects on the body's endrocrine system [2]. The exact mechanism through which AM causes contraception is not yet understood, but most oral contraceptives affect the steroidogenesis pathway through either increasing or decreasing hormones or their related receptor levels or affecting the activities of the enzymes involved [8,9]. One of the enzymes present in the steroidogenesis pathway is $5 \alpha$-reductase $(5 \alpha-R)$, which converts testosterone (T) to $5 \alpha$-DHT through the reduction of the $\Delta^{4,5}$ double bond [10]. Overproduction of $5 \alpha$-DHT, a much more potent androgen, causes androgen-dependent diseases such as benign prostate cancer, acne and androgenic alopecia (AGA) [10]. Of these diseases, AGA is the main focus of this research work.

AGA is the major type of scalp hair loss in humans, affecting some $60 \%-70 \%$ of the worldwide population $[11,12]$. It affects $50 \%$ of males by the age of 50 and up to $70 \%$ of all males in their later life, while it affects only $25 \%$ of women by the age of $49 \%$ and $41 \%$ by the age of 69 years [13]. It is characterized by the miniaturization of the large, thick pigmented terminal hairs with diameters of greater than $0.03 \mathrm{~mm}$ into small, fine, non-pigmented vellus hairs with a diameter of $0.03 \mathrm{~mm}$ or less $[11,14]$. The miniaturization, due to the overproduction of $5 \alpha$-DHT, results in the premature entry of the hair follicle into the catagen (transition) phase and the delay in the transition from the telogen (resting) to anagen (growth) phase, resulting in the shortening of the growth phase [15]. Therefore, one potential target for treating AGA is to inhibit this enzymatic reaction within the hair follicle. Two isoforms of this enzyme has been identified in different parts of the hair follicle, namely $5 \alpha-\mathrm{R} 1$ and $5 \alpha-\mathrm{R}$ type 2

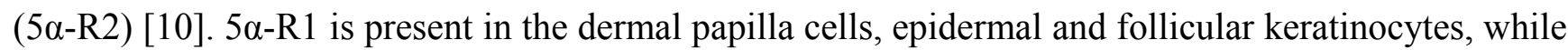
$5 \alpha-\mathrm{R} 2$ is present in the inner layer of the outer root sheath, inner root sheath, interfollicular keratinocytes and might be present in the dermal papilla cells [16,17]. Different isoforms that catalyze the same reduction reaction are thus present in different parts of the hair follicle, however, only the dermal papilla cells are the site of action of $5 \alpha$-DHT. In addition, they are the main regulator of hair growth as it plays an essential role in induction of new hair follicles and maintaining hair growth $[18,19]$.

Therefore, in this study a cell-based assay system using dermal papilla cells commercially available as HHDPCs was used in order to evaluate the potential of AM as an $5 \alpha-\mathrm{R}$ inhibitor, specifically for treating AGA. The assay system was coupled with a non-radioactive TLC detection technique. 
In addition, activity-guided fractionation through a preparative TLC technique was carried out in order to obtain pure bioactive compound(s) from the AM extract.

\section{Results and Discussion}

\subsection{Expression of $5 \alpha-R 1$ in HHDPCs}

$5 \alpha-\mathrm{R}$ is responsible for the conversion of $\mathrm{T}$ into $5 \alpha$-DHT causing AGA. Therefore, the presence of this enzyme within the HHDPCs was evaluated. The RT-PCR analysis revealed that the genes of $5 \alpha-\mathrm{R} 1$ were expressed in passages 2, 4, 5 and 6 of HHDPCs, while $5 \alpha-\mathrm{R} 2$ was not expressed in any of the passages (Figure 1). $\beta$-Actin, used as an internal control, was constantly expressed in all passages.

Figure 1. RT-PCR showing the expression of $5 \alpha$-Rs and $\beta$-actin within HHDPCs. A $1 \%$ agarose gel showing, from the top, the expression of $5 \alpha-\mathrm{R} 1$ ( $5 \alpha$-reductase type 1, $380 \mathrm{bp}$ ), $5 \alpha$-R2 (5 $\alpha$-reductase type 2, $440 \mathrm{bp}$ ) and $\beta$-actin (584 bp) within passages 2, 4, 5 and 6 of HHDPCs. The 1-kb DNA ladder (L) shows the band sizes of $1 \mathrm{~kb}$ and 750, 500 and $250 \mathrm{bp}$ from the top down.

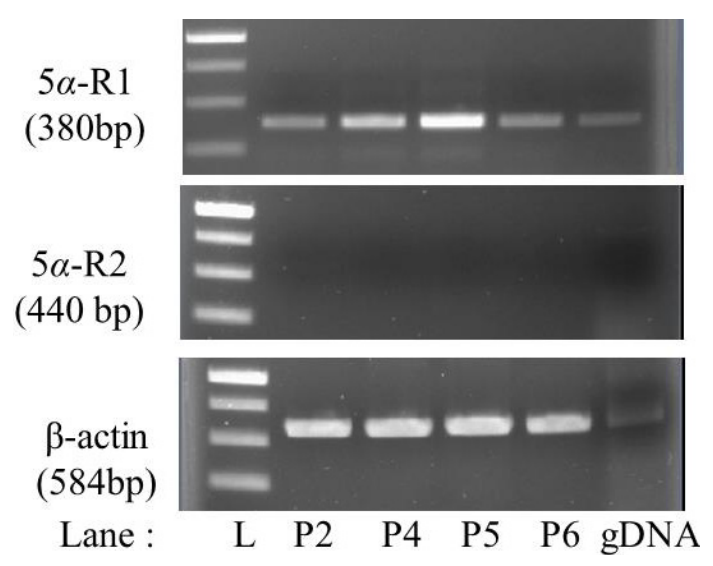

These results suggested that the type 1 enzyme, not type 2 , is likely to have a direct role in hair growth regulation. This corresponds with previous works showing that the predominant form of $5 \alpha-\mathrm{R}$ in HHDPC is $5 \alpha-\mathrm{R} 1[10,16,17]$. The two isoforms have $47 \%$ sequence similarity [10] and are known to be specifically distributed in different organs within the human body $[10,16]$. However, finding a number of reports in the literature that use $5 \alpha-\mathrm{R} 2$ as the target enzyme for screening anti-AGA compounds is interesting [20-22]. This might be due to the previous clinical studies results showing that finasteride, a selective 5 $\alpha-\mathrm{R} 2$ inhibitor, decreases the $5 \alpha$-DHT concentration and promotes hair growth in men with AGA [16,23]. This effect has been explained based on the results of immunohistochemical localization of $5 \alpha-\mathrm{R} 2$ within the inner root sheath keratinocytes in the hair follicle rather than its direct effect on $5 \alpha-\mathrm{R} 1$ within the HHDPCs which are known to be the main regulators of hair growth $[10,16,17,24]$.

\subsection{AM as 5a-R1 Inhibitor}

Overproduction of $5 \alpha$-DHT is caused by $5 \alpha-\mathrm{R}$, therefore one potential target to treat AGA is to inhibit this enzymatic reaction. A lot of research has been conducted using different cell types (e.g., 
transfected rat [25] or insect [21] cell lines) for a cell-based assay, or 5 $\alpha$-R enzymes isolated from unrelated organs (e.g., rat liver [26-28], prostate [29,30], epididymis [20] or human prostate [31]) for a cell-free assay. The use of these indirect cells or $5 \alpha-\mathrm{R}$ enzymes has raised questions on the reliability of the available assays, therefore, we have developed a new cell-based assay using the appropriate target cells of the hair follicle, HHDPCs which are involved in hair growth and AGA.

The developed HHDPC-based assay system was used to evaluate the $5 \alpha-\mathrm{R} 1$ inhibitory activity potential of AM, using dutasteride, a well-known potent inhibitor, as a positive control. The inhibitory activity was detected at $366 \mathrm{~nm}$ on the TLC plates based on the amount of $5 \alpha$-DHT produced relative to the internal control $(\mathrm{Cell}+\mathrm{T})$, through a simple method of dipping the developed silica gel $60 \mathrm{~F}_{254}$ aluminum TLC plate into $42.5 \%$ phosphoric acid and then heating it at $120{ }^{\circ} \mathrm{C}$ for $20 \mathrm{~min}$. As non-radiolabelled $\mathrm{T}$ was used as the substrate, the visual detection of $5 \alpha$-DHT produced was recordable at $366 \mathrm{~nm}$ using a TLC imager. There was no need to use the complicated detection techniques reported so far, which include radioactive image analyzers [27,30], TLC radioactive scanners [25], and HPLC radioactive detectors [21], or measuring the decrease in the radiolabelled $\mathrm{T}$ concentration using HPLC [20,28,29,31].

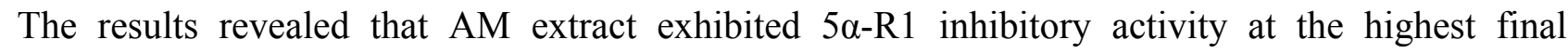
non-toxic concentration of $10 \mu \mathrm{g} / \mathrm{mL}$ as it significantly $(p<0.05)$ reduced $5 \alpha$-DHT production by $52 \%$ compared to a non-significant reduction of $6.65 \%$ at $5 \mu \mathrm{g} / \mathrm{mL}$ (Figure 2). Dutasteride exhibited complete inhibition at 0.1 and $0.01 \mu \mathrm{g} / \mathrm{mL}$, while showing $16.5 \%$ reduction in $5 \alpha$-DHT production at $0.001 \mu \mathrm{g} / \mathrm{mL}$. The viability of the attached cells in the 96 -well plate was $100.5 \% \pm 2.02 \%(n=3)$, confirming the non-toxic effect of the AM extract.

Figure 2. $5 \alpha-\mathrm{R} 1$ inhibitory activity of $\mathrm{AM}$ at 5 and $10 \mu \mathrm{g} / \mathrm{mL}(6.65 \%$ and $52 \%$ inhibition, respectively) and dutasteride at $1,0.01$ and $0.001 \mu \mathrm{g} / \mathrm{mL}(0 \%, 0 \%$ and $16.5 \%$ inhibition, respectively) using HHDPC-based assay system coupled with non-radioactive TLC detection technique. Cell+T is the internal control.

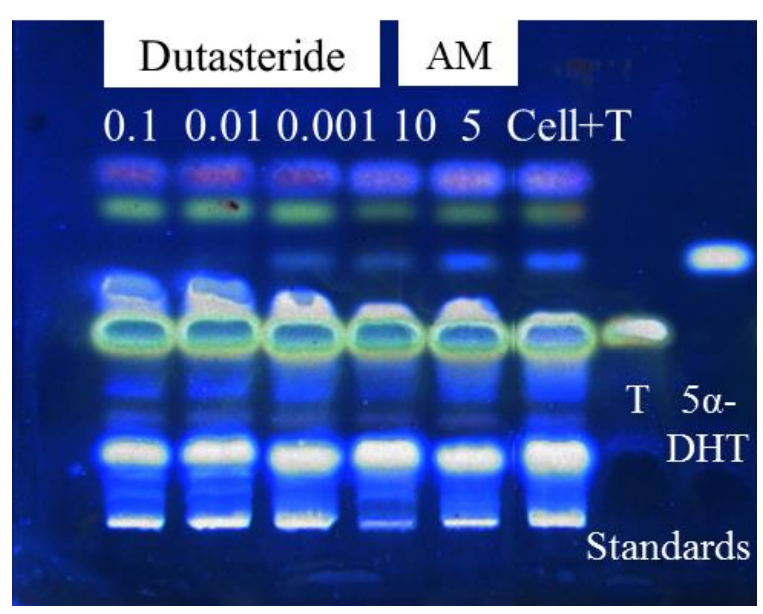

\subsection{TLC Profile and Activity-Guided Fraction of AM}

The chemical complexity of AM extract was first observed by TLC. By using a silica gel plate and a mobile phase of toluene-acetonitrile-ethyl acetate-acetic acid in the ratio of 7:1:3:0.03, the constituents of AM appeared to be well separated as observed under the wavelengths of 254 
and $366 \mathrm{~nm}$ (Figure 3a). Therefore, the preparative TLC technique was used to fractionate each observed band as fractions. Eight fractions were obtained from the preparative TLC, each of which showed clearly the presence of main constituent(s), especially at $366 \mathrm{~nm}$ (Figure 3b). Each fraction was then tested for $5 \alpha-\mathrm{R} 1$ inhibitory activity at the final concentration of $10 \mu \mathrm{g} / \mathrm{mL}$, and the results are shown in Figure 4. It can be clearly seen that fraction "4", which is a mixture of at least three compounds, exhibited similar $5 \alpha-\mathrm{R} 1$ inhibitory activity to that of the methanolic crude extract of AM. Therefore, further purification of this fraction was carried out using a double developing TLC system of toluene-acetonitrile in the ratio of $8: 2$ as the mobile phase, which lead to the isolation of two blue compounds and one green compound labeled as B1, B2 and G1 (Figure 3c).

Figure 3. (a) TLC profile of the methanolic heartwood extract of AM visualized at 254 and $366 \mathrm{~nm}$; (b) TLC plate visualized at $366 \mathrm{~nm}$ showing the isolated fractions; (c) Separation of B1, B2 and G1 from fraction "4" through double development of the TLC plate in 8:2 toluene-acetonitrile.

\section{$254 \mathrm{~nm} \quad 366 \mathrm{~nm}$}

(a)

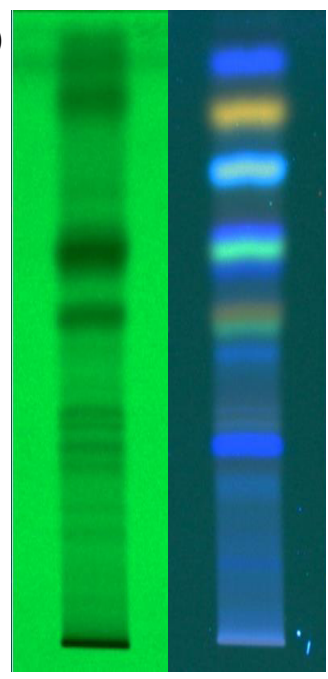

(b)

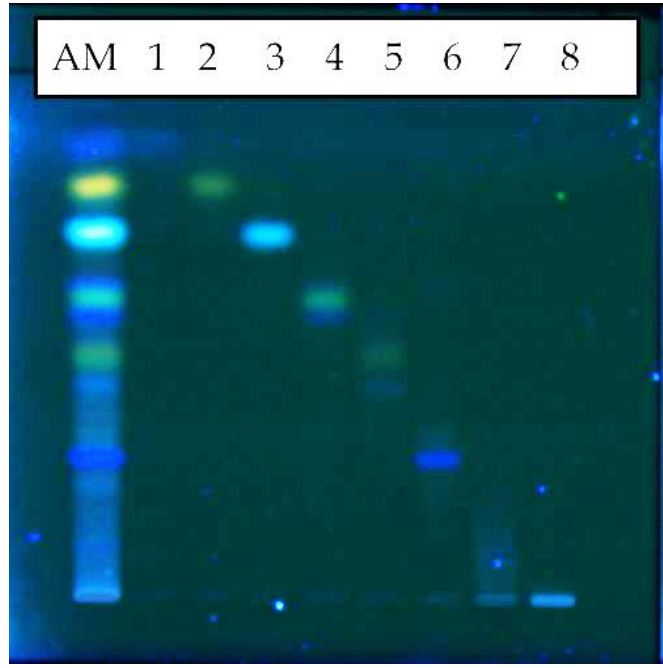

(c)

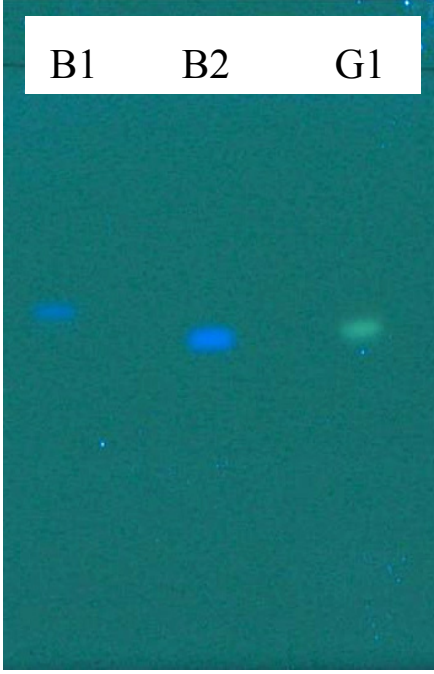

Figure 4. $5 \alpha-\mathrm{R} 1$ inhibitory activity assay of the eight AM fractions numbering 1-8 with 0 , $19.2 \%, 13.3 \%, 50 \%, 18.9 \% 10.7 \%, 5.7 \%$ and $17.1 \%$ inhibition, respectively, comparing with the original AM extract (52\% inhibition) using HHDPC-based assay system coupled with non-radioactive TLC detection technique. Cell+T is the internal control and Cell- $\mathrm{T}$ is the negative control.

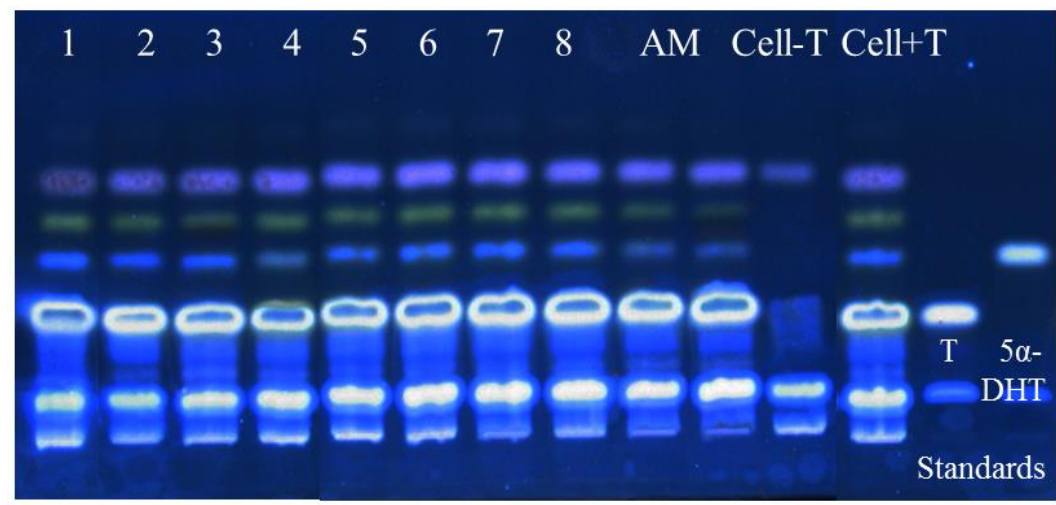


Each compound at the final concentration of $10 \mu \mathrm{g} / \mathrm{mL}$ was again tested for $5 \alpha-\mathrm{R} 1$ inhibitory activity. As shown in Figure 5a, only G1 alone showed 5 $\alpha-\mathrm{R} 1$ inhibitory activity similar to that of AM with a $50 \%$ reduction in $5 \alpha$-DHT production, giving an $\mathrm{IC}_{50}$ of $9.94 \pm 0.33 \mu \mathrm{g} / \mathrm{mL}$ (Figure $5 \mathrm{~b}$ ) while $\mathrm{B} 1$ and $\mathrm{B} 2$ showed only $15 \%$ and $12 \%$ inhibitory activity, respectively.

Figure 5. (a) $5 \alpha-\mathrm{R} 1$ inhibitory activity of $\mathrm{B} 1, \mathrm{~B} 2$ and $\mathrm{G} 1$ at the final concentration of $10 \mu \mathrm{g} / \mathrm{mL}$; and (b) Dose-dependent response of G1 at 1.25, 2.5, 5 and $10 \mu \mathrm{g} / \mathrm{mL}(25.5 \%$, $33.2 \%, 36.3 \%$ and $52 \%$ inhibition, respectively). Cell+T is the internal control and Cell-T is the negative control.

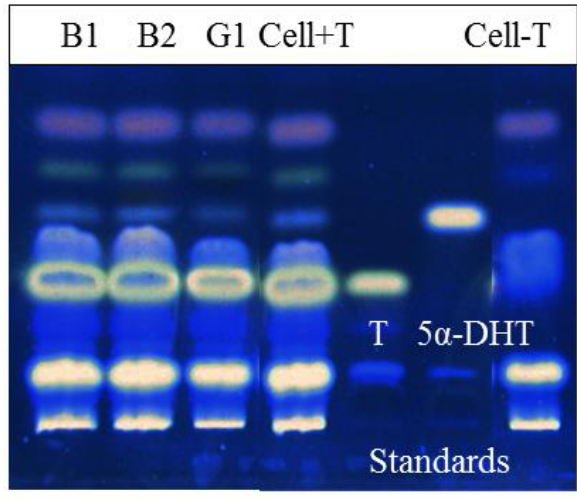

(a)

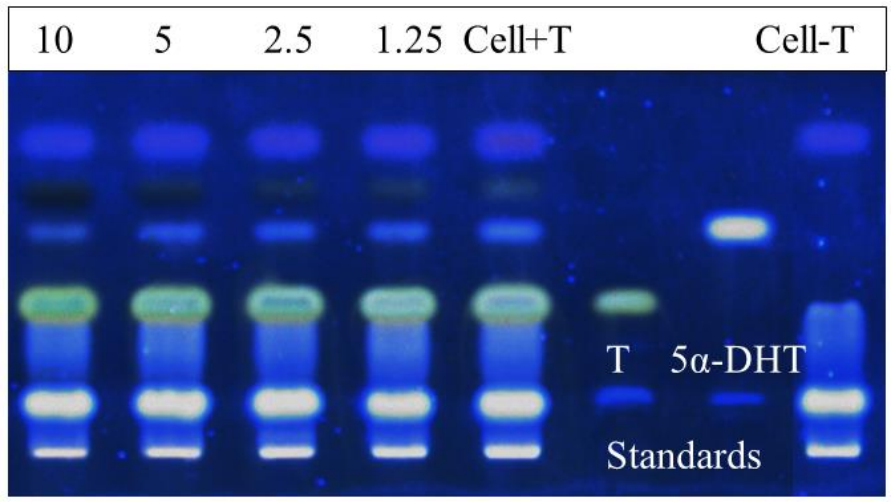

(b)

Subsequently, G1 obtained from the preparative TLC was further purified by semi-preparative HPLC. This was achieved through the application of $45 \mathrm{mg}$ of G1 in $450 \mu \mathrm{L}$ of DMSO to a TSK gel ODS $(2 \times 25 \mathrm{~cm}, 5 \mu \mathrm{m})$ column using $30 \%$ acetonitrile as a mobile phase with a flow rate of $9 \mathrm{~mL} / \mathrm{min}$. G1 was eluted as a major pure compound peak at a retention time of $78 \mathrm{~min}$ (Figure 6a).

Figure 6. (a) Purity check of G1 compared with AM extract and fraction 4 by a silica gel TLC plate developed by toluene: acetonitrile in the ratio of $8: 2$ and visualized under $366 \mathrm{~nm}$; (b) Structure of G1, identified as avicequinone C.

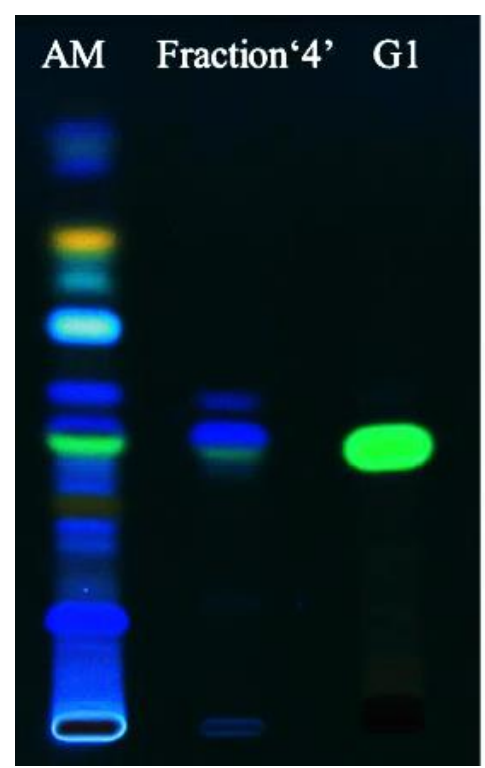

(a)

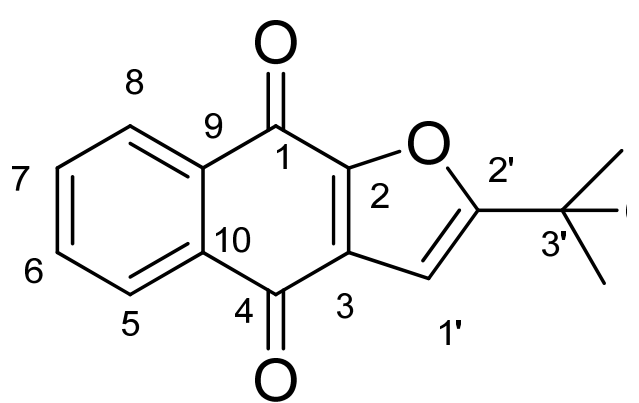

(b) 
NMR analysis of G1 was based on the spectral data of both ${ }^{1} \mathrm{H}-\mathrm{NMR}$ and ${ }^{13} \mathrm{C}-\mathrm{NMR}$. By comparison with previously reported ${ }^{1} \mathrm{H}-\mathrm{NMR}$ and ${ }^{13} \mathrm{C}-\mathrm{NMR}$ data [32,33] (Table 1), G1 was identified as naphtho 2'-(1-hydroxy-1-methylethyl)[2,3- $\beta$ ]furan-1,4-dione, or avicequinone $\mathrm{C}$ (Figure $6 \mathrm{~b}$ ) with a molecular formula of $\mathrm{C}_{15} \mathrm{H}_{12} \mathrm{O}_{4}$ and a molecular weight of 256 .

Table 1. NMR spectra data of $\mathrm{G} 1$ and avicequinone $\mathrm{C}$ in $\mathrm{CDCl}_{3}$.

\begin{tabular}{lllll}
\hline \multirow{2}{*}{ Position } & G1 & \multicolumn{3}{c}{ Avicequinone C [32,33] } \\
\cline { 2 - 5 } & ${ }^{\mathbf{1}} \mathbf{H}(\mathbf{m u l t} ., \boldsymbol{J}$ in Hz) & ${ }^{\mathbf{1 3}} \mathbf{C}$ & ${ }^{\mathbf{1}} \mathbf{H}(\mathbf{m u l t} ., \boldsymbol{J}$ in Hz) & ${ }^{\mathbf{1 3}} \mathbf{C}$ \\
\hline 1 & - & 173.4 & - & 173.3 \\
2 & - & 151.8 & - & 151.6 \\
3 & - & 131.3 & - & 131.2 \\
4 & - & 180.8 & - & 180.7 \\
5 & $8.16(\mathrm{~m})$ & 126.9 & $8.14(\mathrm{~m})$ & 126.8 \\
6 & $7.75(\mathrm{~m})$ & 133.9 & $7.73(\mathrm{~m})$ & 133.9 \\
7 & $7.75(\mathrm{~m})$ & 133.7 & $7.73(\mathrm{~m})$ & 133.7 \\
8 & $8.21(\mathrm{~m})$ & 126.8 & $8.18(\mathrm{~m})$ & 126.8 \\
9 & - & 132.5 & - & 132.4 \\
10 & - & 133.1 & - & 102.6 \\
\hline $1^{\prime}$ & $6.82(\mathrm{~s})$ & 102.6 & $6.80(\mathrm{~s})$ & 168.1 \\
$2^{\prime}$ & - & 167.9 & - & 69.3 \\
$3^{\prime}$ & - & 69.4 & - & 28.7 \\
$4^{\prime}$ & $1.69(\mathrm{~s})$ & 28.8 & $1.67(\mathrm{~s})$ & 28.7 \\
$5^{\prime}$ & $1.69(\mathrm{~s})$ & 28.8 & $1.67(\mathrm{~s})$ & \\
\hline
\end{tabular}

Avicequinone $\mathrm{C}$ has a furanonaphthaquinone structure. It was first isolated from $\mathrm{AM}$ in 2000 by Ito. et al. [32]. The compound has been shown to have antimicrobial and antiproliferative activities [34]. In this study, avicequinone $\mathrm{C}$ showed its $5 \alpha-\mathrm{R} 1$ inhibitory activity, with an $\mathrm{IC}_{50}$ value of $38.8 \pm 1.29 \mu \mathrm{M}$. Although this value indicates moderate potency, it is still better than or equivalent to the reported $\mathrm{IC}_{50}$ values of many natural products isolated from plants, for example, the $\mathrm{IC}_{50}$ values of $112 \mu \mathrm{M}$ for soyasaponin1 from Pueraria thomsonii [20], $85 \mu \mathrm{M}$ for artocarpin from Artocarpus incises [35], $40 \mu \mathrm{M}$ for emodin from Polygonum multiflorum Thunb [36], $31.7 \mu \mathrm{M}$ for triolin from Torillis japonica [37], $390 \mu \mathrm{M}, 230 \mu \mathrm{M}, 220 \mu \mathrm{M}$ and $220 \mu \mathrm{M}$ for 1,7-diphenylhept-4-en-3-one, dihydroyashabushiketol, 5-hydroxy-7-(4"-hydroxy-3"-methoxyphenyl)-1-phenyl-3-heptanone and 5-hydroxy-7-(4"-hydroxyphenyl) -1-phenyl-3-heptanone from Alpinia officinarum [38] and $44 \mu \mathrm{M}, 103 \mu \mathrm{M}$ and $48 \mu \mathrm{M}$ for (-)-cubebin, (-)-3,4-dimethoxy-3,4-desmethylenedioxycubebin and piperine from Piper nigrum, respectively [39].

The presence of the 1,4-naphthoquinone nucleus of avicequinone $\mathrm{C}$ might be important for the activity, as it is in alizarin, which exhibited $5 \alpha-\mathrm{R} 1$ inhibitory activity in both cell-free and cell-based assays with $\mathrm{IC}_{50}$ values of 3 and $6 \mu \mathrm{M}$, respectively [25]. Purpurin, an anthraquinone, also exhibited $5 \alpha-\mathrm{R} 1$ inhibitory activity in a cell-free assay with an $\mathrm{IC}_{50}$ of $2 \mu \mathrm{M}$ [25]. However, to date only these two naphthoquinones have been identified as $5 \alpha-\mathrm{R}$ inhibitors and no structure-activity relationships have been conducted on this group of compounds. 


\section{Experimental}

\subsection{Chemicals, Enzymes and Reagents}

All of the organic solvents used were analytical grade and purchased from RCI Labscan (Bangkok, Thailand). Ultrapure grade dimethyl sulfoxide (DMSO) was purchased from Ameresco ${ }^{\circledR}$ (Framingham, MA, USA). T and 5 $\alpha$-DHT were purchased from Sigma-Aldrich (St. Louis, MO, USA). Dutasteride was purchased from BDG Synthesis (Wellington, New Zealand). Agarose-LE was purchased from Affymetrix (Santa Clara, CA, USA). Mesenchymal stem cell medium and its supplements were purchased from Sciencell Research Laboratories (Carlsbad, CA, USA). Fetal bovine serum, 100× antibiotic-antimycotic solution, 10× PrestoBlue $^{\circledR}$ (Life Technologies, Carlsbad, CA, USA), RPMI medium, 50× Tris-acetate-EDTA (TAE) buffer, $0.25 \%$ trypsin-EDTA and Platinum ${ }^{\circledR}$ Taq polymerase kit were purchased from Invitrogen (Grand Island, New York, NY, USA). A GeneRuler 1-kb DNA ladder was purchased from Thermo Fisher Scientific (Pittsburgh, PA, USA). RNeasy ${ }^{\circledR}$ mini kit was purchased from Qiagen (Valencia, CA, USA). DNase I enzyme, EDTA, first-strand cDNA synthesis kit, dATP, dTTP, dCTP and dGTP were purchased from Fermentas (Waltham, MA, USA).

\subsection{Plant Material and Extraction}

The heartwood of AM was obtained from a local Thai-Chinese medicinal store and was first ground into powder and further subjected to maceration using $100 \%$ methanol at room temperature for two days. The methanolic extract was then evaporated to dryness at $45{ }^{\circ} \mathrm{C}$ using a rotary evaporator (Rotavapor R-210, Buchi, Flawil, Switzerland) and kept at $-20{ }^{\circ} \mathrm{C}$ until used.

\subsection{Culturing of HHDPCs}

HHDPCs, obtained from Sciencell Research Laboratories, were grown in mesenchymal stem cell medium containing 5\% fetal bovine serum (FBS), mesenchymal stem cell medium supplement, and $1 \times$ antibiotic-antimycotic solution at $37^{\circ} \mathrm{C}$ in $5 \% \mathrm{CO}_{2}$. The cells between passages 2 to 6 were used in this study.

\subsection{Checking for the Presence of $5 \alpha-R$ in the HHDPCs}

Reverse-transcriptase polymerase chain reaction (RT-PCR) was used to identify the isoforms of $5 \alpha-\mathrm{R}$ (i.e., $5 \alpha-\mathrm{R} 1$ and/or 5 $\alpha-\mathrm{R} 2$ ), expressed in HHDPCs from passages 2, 4, 5 and 6 . The forward and reverse primers for the two isoforms of $5 \alpha-\mathrm{R}$ and $\beta$-actin, shown in the Table 2, were designed from the protein region of the full length sequence obtain from the NCBI GenBank using Clone Manager (Scientific \& Educational Software, Cary, NC, USA) and made to order at 1st Base Laboratories (Selangor, Malaysia). The PCR products were analyzed using 1\% agarose gel electrophoresis. 
Table 2. Forward and reverse primers and expected sizes of $5 \alpha$-Rs and $\beta$-actin.

\begin{tabular}{llc}
\hline \multicolumn{1}{c}{ Name } & \multicolumn{1}{c}{ Primer pair } & Expected size (bp) \\
\hline 5 $\alpha$-reductase type 1 $(5 \alpha-\mathrm{R} 1)$ & F:5' ACTGCATCCTCCTGGCCATGTTC 3' & \multirow{2}{*}{380} \\
GenBank: NM_001047.2 & R:5' GGCATAGCCACACCACTCCATGA 3' & \\
5 $\alpha$-reductase type 2 $(5 \alpha-R 2)$ & F:5' AAGCACACGGAGAGCCTGAA 3' & \multirow{2}{*}{450} \\
GenBank: NM_000348.3 & R:5' GCCACCTTGTGGAATCCTGTAGC 3' & \\
$\beta$-actin (internal control) & F:5' ATGATGATATCGCCGCGCTC 3' & \multirow{2}{*}{584} \\
GenBank: NM_001101.3 & R:5' GCGCTCGGTGAGGATCTTCA 3' & \\
\hline
\end{tabular}

\subsection{Cytotoxicity of AM on HHDPC}

In order to obtain a suitable starting concentration for testing the inhibitory activity, the highest non-toxic concentration of AM was determined. HHDPCs were seeded at a cell density of $1 \times 10^{5}$ cells $/ \mathrm{mL}$ onto 96-well plates (100 $\mu \mathrm{L}$ of 10,000 cells/well). After $24 \mathrm{~h}$, the cells were separately treated with $100 \mu \mathrm{L}$ of AM or $1 \%$ DMSO (control). The concentration of AM ranges from $40,20,10$ and $5 \mu \mathrm{g} / \mathrm{mL}$ with the final concentrations of $20,10,5$ and $2.5 \mu \mathrm{g} / \mathrm{mL}$, respectively. Cell viability was measured $24 \mathrm{~h}$ after the treatment using $1 \times$ PrestoBlue $^{\circledR}$ (Life Technologies) reagent in RPMI medium. In the presence of viable cells, PrestoBlue ${ }^{\circledR}$ changes from a non-fluorescent blue color to a fluorescent purple-pink color, which is detected using the Multimode Detector DTX 880 (Beckman Coulter ${ }^{\circledR}$, Indianapolis, IN, USA), a bottom-read fluorospectrophotometer with an excitation/emission of 535/615 nm. The results showed that AM was not toxic to HHDPCs, (i.e., cell viability more than 85\%) up to the final concentration of $10 \mu \mathrm{g} / \mathrm{mL}$ of AM. Therefore, this concentration was used as the starting concentration for the $5 \alpha-\mathrm{R} 1$ inhibitory activity test.

\section{6. $5 \alpha-R$ inhibitory Activity Test}

HHDPCs were seeded at a cell density of $1 \times 10^{5}$ cells $/ \mathrm{mL}$ onto 96 -well plates $(100 \mu \mathrm{L}$ of 10,000 cells/well). After $24 \mathrm{~h}$, the cells were separately treated with $50 \mu \mathrm{L}$ of $4 \times 10^{-4} \mathrm{M} \mathrm{T}$ and $50 \mu \mathrm{L}$ of $2 \%$ DMSO (internal control); $50 \mu \mathrm{L}$ of $4 \times 10^{-4} \mathrm{M} \mathrm{T}$ and $50 \mu \mathrm{L}$ of $40 \mu \mathrm{g} / \mathrm{mL} \mathrm{AM}$; and $100 \mu \mathrm{L}$ of $2 \%$ DMSO (negative control). The cells were treated for $48 \mathrm{~h}$, before the cell culture medium was collected in Eppendorf tubes, and the attached cells were tested for cell viability using the $1 \times$ PrestoBlue $^{\circledR}$ (Life Technologies) reagent in RPMI medium in order to avoid false positive result. $\mathrm{T}$ and its product, $5 \alpha$-DHT, were extracted from the cell culture medium using an equal volume of ethyl acetate. The ethyl acetate fraction was then dried, reconstituted with $20 \mu \mathrm{L}$ of methanol and spotted on a TLC Silica gel $60 \mathrm{~F}_{254}$ aluminum plate (Merck, Darmstadt, Germany). The TLC plate was developed using toluene-acetone at a ratio of 8:2 as the mobile phase [30]. The developed TLC plate was dipped in a solution of $42.5 \%$ phosphoric acid and heated at $120{ }^{\circ} \mathrm{C}$ for $20 \mathrm{~min}$, for the visual detection of $5 \alpha$-DHT at $366 \mathrm{~nm}$ using a TLC reprostar imager (Camag, Muttenz, Switzerland), and the amount was quantified using an image analyzing program, Quantity One (Bio-Rad, Hercules, CA, USA). The inhibitory activity was determined through the decrease in $5 \alpha$-DHT production relative to the internal control. 


\subsection{TLC Profile of AM}

TLC was used to observe the complexity of the methanolic heartwood extract of AM. The TLC silica gel $60 \mathrm{~F}_{254}$ aluminum plate was spotted with $10 \mu \mathrm{L}$ of $\mathrm{AM}$ at the concentration of $3.5 \mathrm{mg} / \mathrm{mL}$ and was developed in toluene-acetonitrile-ethyl acetate-acetic acid in the ratio of 7:1:3:0.03 as the mobile phase. The developed plate was then visualized under the wavelengths of 254 and $366 \mathrm{~nm}$.

\subsection{Isolation and Structural Analysis of Bioactive Compound(s) within AM}

Preparative TLC was used to separate and isolate the compounds in AM. The extract was developed, using the same system as mentioned above, on a preparative TLC Silica gel $60 \mathrm{~F}_{254}$ glass plate and each band/fraction was isolated through scraping. The bands/fractions were then tested for $5 \alpha-\mathrm{R}$ inhibitory activity using the developed assay system. The purity of active compound(s) were checked using HPLC before structure elucidations were conducted using ${ }^{1} \mathrm{H}-\mathrm{NMR}$ and ${ }^{13} \mathrm{C}-\mathrm{NMR}$ : ${ }^{1} \mathrm{H}-\mathrm{NMR}\left(400 \mathrm{MHz}, \mathrm{CDCl}_{3}\right) \delta_{\mathrm{H}}$ (mult $(J$ in $\left.\mathrm{Hz}) ; \mathrm{H}\right): 8.16(m ; 1 \mathrm{H}, \mathrm{H}-5), 8.21(m ; 1 \mathrm{H}, \mathrm{H}-8), 7.75(m ; 2 \mathrm{H}$, H-6, H-7), $6.82\left(s ; 1 \mathrm{H}, \mathrm{H}-1^{\prime}\right), 1.69\left(s ; 2 \mathrm{H}, \mathrm{H}-4\right.$ ', H-5'); ${ }^{13} \mathrm{C}-\mathrm{NMR}\left(100 \mathrm{MHz}, \mathrm{CDCl}_{3}\right) \delta \mathrm{c}: 173.4(\mathrm{C}-1)$, 151.8 (C-2), 131.3 (C-3), 180.8 (C-4), 126.9 (C-5), 133.9 (C-6), 133.7 (C-7), 126.8 (C-8), 132.5 (C-9), 133.1 (C-10), $102.6\left(\mathrm{C}-1^{\prime}\right), 167.9$ (C-2'), 69.4 (C-3'), 28.8 (C-4', C-5').

\subsection{Statistical Analysis}

All of the experiments were performed in triplicate, and the data are presented as the means \pm SD. One-way single factor ANOVA was used and a $p$-value $<0.05$ was taken to be statistically significant.

\section{Conclusions}

A natural furanonaphthaquinone exhibiting $5 \alpha-\mathrm{R} 1$ inhibitory activity $\left(\mathrm{IC}_{50}\right.$ of $\left.38.8 \pm 1.29 \mu \mathrm{M}\right)$ and identified as avicequinone $\mathrm{C}$, a known compound, was successfully isolated from the heartwood of AM. This was accomplished by a simple activity-guided fractionation using TLC as a tool for both the cell-based assay detection and compound isolation. In addition, HHDPCs was used in this cell-based assay due to its properties of being the main regulator of hair growth as they are the only cells within the hair follicle that are the direct site of $5 \alpha$-DHT action, and therefore, considered to be the right target and used for the first time to screen for anti-AGA compounds. Further studies on the modification of avicequinone $\mathrm{C}$ might lead to more potent $5 \alpha-\mathrm{R} 1$ inhibitors with higher potential in treating AGA.

\section{Acknowledgments}

This study was financially supported through collaborative activities between ICS-UNIDO and Chulalongkorn University. Ruchy Jain would like to thank Chulalongkorn University for a Ph.D. scholarship under the Chula Dusadee Pipat Project.

\section{Author Contributions}

Ruchy Jain: Experimental design and conduct, data analysis and manuscript preparation; Orawan Monthakantirat: Preparation of plant crude extracts and structure elucidation; Parkpoom Tengamnuay: 
Co-supervisor of Ruchy Jain, giving comments and suggestions; Wanchai De-Eknamkul: Main supervisor of Ruchy Jain, project leader, giving comments and suggestions and manuscript preparation.

\section{Conflicts of Interest}

The authors declare no conflict of interest.

\section{References}

1. Zhu, F.; Chen, X.; Yuan, Y.; Huang, M.; Sun, H.; Xiang, W. The chemical investigations of the mangrove plant Avicennia marina and its endophytes. Open Nat. Prod. J. 2009, 2, 24-32.

2. Liebezeit, G.; Rau, M.T. New Guinean mangroves-Traditional usage and chemistry of natural products. Senckenb. Maritima 2006, 36, 1-10.

3. Bandaranayake, W. Traditional and medicinal uses of mangroves. Mangroves Salt Marshes 1998, 2, 133-148.

4. Vinod Prabhu, V.; Guruvayoorappan, C. Phytochemical screening of methanolic extract of mangrove Avicennia marina (Forssk.) Vierh. Pharm. Sin. 2012, 3, 64-70.

5. Sukhramani, P.S.; Vidyasagar, G.; Patel, P.M. Biological screening of Avicennia marina for anticancer activity. Pharm. Sin. 2013, 4, 125-130.

6. Khafagi, I.; Gab-Alla, A.; Salama, W.; Fouda, M. Biological activities and phytochemical constituents of the gray mangrove Avicennia marina (Forssk.) Vierh. Egypt. J. Biol. 2003, 5, 62-69.

7. Patra, J.K.; Thatoi, H.N. Metabolic diversity and bioactivity screening of mangrove plants: A review. Acta Physiol. Plant. 2011, 33, 1051-1061.

8. Hsueh, A.; Wang, C.; Erickson, G. Direct inhibitory effect of gonadotropin-releasing hormone upon follicle-stimulating hormone induction of luteinizing hormone receptor and aromatase activity in rat granulosa cells. Endocrinology 1980, 106, 1697-1705.

9. Dimattina, M.; Albertson, B.; Seyler, D.E.; Loriaux, D.L.; Falk, R.J. Effect of the antiprogestin RU486 on progesterone production by cultured human granulosa cells: Inhibition of the ovarian 3B-hydroxysteroid dehydrogenase. Contraception 1986, 34, 199-206.

10. Azzouni, F.; Godoy, A.; Li, Y.; Mohler, J. The 5 alpha-reductase isozyme family: A review of basic biology and their role in human diseases. Adv. Urol. 2011, doi:10.1155/2012/530121.

11. Tobin, D.J. The biogenesis and growth of human hair. In Hair Toxicology-An Important Bio-Monitor; The Royal Society of Chemistry: Cambridge, UK, 2005.

12. Price, V.H. Androgenetic alopecia in women. In Journal of Investigative Dermatology Symposium Proceedings; Nature Publishing Group: London, UK, 2003; pp. 24-27.

13. Dinh, Q.Q.; Sinclair, R. Female pattern hair loss: Current treatment concepts. Clin. Interv. Aging 2007, 2, 189-199.

14. Stough, D.; Stenn, K.; Haber, R.; Parsley, W.M.; Vogel, J.E.; Whiting, D.A.; Washenik, K. Psychological effect, pathophysiology, and management of androgenetic alopecia in men. Mayo Clin. Proc. 2005, 80, 1316-1322.

15. Itami, S.; Inui, S. Role of androgen in mesenchymal epithelial interactions in human hair follicle. J. Investig. Dermatol. Symp. Proc. 2005, 10, 209-211. 
16. Chen, W.; Orfanos, C. The 5 $\mathrm{\alpha}$-reductase system and its inhibitors. Dermatology 1996, 193, 177-184.

17. Bayne, E.; Flanagan, J.; Einstein, M.; Ayala, J.; Chang, B.; Azzolina, B.; Whiting, D.; Mumford, R.; Thiboutot, D.; Singer, I. Immunohistochemical localization of types 1 and 2 5-reductase in human scalp. Br. J. Dermatol. 1999, 141, 481-491.

18. Messenger, A.G. The control of hair growth: An overview. J. Investig. Dermatol. 1993, 101, 4S-9S.

19. Rho, S.-S.; Park, S.-J.; Hwang, S.-L.; Lee, M.-H.; Kim, C.D.; Lee, I.-H.; Chang, S.-Y.; Rang, M.-J. The hair growth promoting effect of Asiasari radix extract and its molecular regulation. J. Dermatol. Sci. 2005, 38, 89-97.

20. Murata, K.; Noguchi, K.; Kondo, M.; Onishi, M.; Watanabe, N.; Okamura, K.; Matsuda, H. Inhibitory activities of Puerariae Flos against testosterone $5 \alpha$-reductase and its hair growth promotion activities. J. Nat. Med. 2012, 66, 158-165.

21. Raynaud, J.-P.; Cousse, H.; Martin, P.-M. Inhibition of type 1 and type $25 \alpha$-reductase activity by free fatty acids, active ingredients of Permixon ${ }^{\circledR}$. J. Biochem. Mol. Biol. 2002, 82, 233-239.

22. Pais, P. Potency of a novel saw palmetto ethanol extract, SPET-085, for inhibition of 5a-reductase II. Adv. Ther. 2010, 27, 555-563.

23. Ellis, J.A.; Sinclair, R.; Harrap, S.B. Androgenetic alopecia: Pathogenesis and potential for therapy. Expert Rev. Mol. Med. 2002, 2, 1-11.

24. Eicheler, W.; Dreher, M.; Hoffmann, R.; Happle, R.; Aumüller, G. Immunohistochemical evidence for differential distribution of $5 \alpha$-reductase isoenzymes in human skin. Br. J. Dermatol. 1995, 133, 371-376.

25. Hiipakka, R.A.; Zhang, H.-Z.; Dai, W.; Dai, Q.; Liao, S. Structure-activity relationships for inhibition of human 5 $\alpha$-reductases by polyphenols. Biochem. Pharmacol. 2002, 63, 1165-1176.

26. Matsuda, H.; Yamazaki, M.; Naruto, S.; Asanuma, Y.; Kubo, M. Anti-androgenic and hair growth promoting activities of Lygodii Spora (Spore of Lygodium japonicum) I. Active constituents inhibiting testosterone 5alpha-reductase. Biol. Pharm. Bull. 2002, 25, 622-626.

27. Liu, J.; Kurashiki, K.; Shimizu, K.; Kondo, R. Structure-activity relationship for inhibition of $5 \alpha$-reductase by triterpenoids isolated from Ganoderma lucidum. Bioorg. Med. Chem. 2006, 14, 8654-8660.

28. Kumar, N.; Rungseevijitprapa, W.; Narkkhong, N.-A.; Suttajit, M.; Chaiyasut, C. $5 \alpha$-reductase inhibition and hair growth promotion of some Thai plants traditionally used for hair treatment. J. Ethnopharmacol. 2012, 139, 765-771.

29. Kumar, T.; Chaiyasut, C.; Rungseevijitprapa, W.; Suttajit, M. Screening of steroid 5 $\alpha$-reductase inhibitory activity and total phenolic content of Thai plants. J. Med. Plants Res. 2011, 5, 1265-1271.

30. Roh, S.-S.; Kim, C.D.; Lee, M.-H.; Hwang, S.-L.; Rang, M.-J.; Yoon, Y.-K. The hair growth promoting effect of Sophora flavescens extract and its molecular regulation. J. Dermatol. Sci. 2002, 30, 43-49.

31. Pandit, S.; Chauhan, N.S.; Dixit, V. Effect of Cuscuta reflexa Roxb on androgen-Induced alopecia. J. Cosmet. Dermatol. 2008, 7, 199-204.

32. Ito, C.; Katsuno, S.; Kondo, Y.; Tan, H.; Furukawa, H. Chemical consituents of avicennia alba. isolation and structural elucidation of new naphthoquinones and their analogues. Chem. Pharm. Bull. 2000, 48, 339-343. 
33. Rui, J.; Yuewei, G.; Huixin, H. Studies on the chemical constituents from leaves of Avicennia marina. Chin. J. Nat. Med. 2004, 2, 16-19.

34. Han, L.; Huang, X.; Dahse, H.-M.; Moellmann, U.; Fu, H.; Grabley, S.; Sattler, I.; Lin, W. Unusual naphthoquinone derivatives from the twigs of Avicennia marina. J. Nat. Prod. 2007, 70, 923-927.

35. Shimizu, K.; Fukuda, M.; Kondo, R.; Sakai, K. The 5 $\alpha$-reductase inhibitory components from heartwood of Artocarpus incisus: Structure-activity investigations. Planta Med. 2000, 66, 16-19.

36. Cho, C.-H.; Bae, J.-S.; Kim, Y.-U. 5 $\alpha$-reductase inhibitory components as antiandrogens from herbal medicine. J. Acupunct. Meridian Stud. 2010, 3, 116-118.

37. Park, W.S.; Son, E.D.; Nam, G.W.; Kim, S.H.; Noh, M.S.; Lee, B.G.; Jang, I.S.; Kim, S.E.; Lee, J.J.; Lee, C.H. Torilin from Torilis japonica, as a new inhibitor of testosterone $5 \alpha$-reductase. Planta Med. 2003, 69, 459-461.

38. Kim, Y.-U.; Son, H.K.; Song, H.K.; Ahn, M.-J.; Lee, S.S.; Lee, S.K. Inhibition of $5 \alpha$-reductase activity by diarylheptanoids from Alpinia officinarum. Planta Med. 2003, 69, 72-74.

39. Hirata, N.; Tokunaga, M.; Naruto, S.; Iinuma, M.; Matsuda, H. Testosterone $5 \alpha$-reductase inhibitory active constituents of Piper nigrum leaf. Biol. Pharm. Bull. 2007, 30, 2402-2405.

Sample Availability: Sample of the compound avicequinone $\mathrm{C}$ is available from the authors.

(C) 2014 by the authors; licensee MDPI, Basel, Switzerland. This article is an open access article distributed under the terms and conditions of the Creative Commons Attribution license (http://creativecommons.org/licenses/by/3.0/). 